\title{
In memoriam \\ prof. dr. sc. Josip Kregar (1953. - 2020.)
}

\author{
UDK: 378-051:34(497.5 Kregar, J.) \\ 929 Kregar, J. \\ DOI: $10.3935 /$ zpfz.70.6.05
}

Dojmljiva i slojevita individualnost Josipa Kregara obilježila je njegovo stvaralaštvo, njegovo djelovanje, prijateljstva i poznanstva, njegov iznenadni odlazak, ali i njegovu daljnju prisutnost. Napustio nas je 13. kolovoza 2020. u 67. godini života.

Josip Kregar rođen je 1. siječnja 1953. u Ogulinu. Osnovnu školu završio je u Novom Vinodolskom, a gimnaziju u Šibeniku. Na Pravnom fakultetu Sveučilišta u Zagrebu diplomirao je 1976. Radio je kao znanstveni istraživač na Institutu za društvena istraživanja od 1976. do 1982., kada započinje radnu karijeru na Pravnom fakultetu u Zagrebu. Iste godine obranio je znanstveni magistarski rad pod naslovom "Politički aspekti odnosa uprave i građana - empirijski test mogućnosti utjecaja”. Zaposlen kao asistent na Katedri za nauku o upravi ubrzo prelazi na Katedru za sociologiju. Važnu okosnicu njegove cjelokupne karijere predstavlja suradnja, mentorstvo i trajan utjecaj koji je na njega imao akademik Eugen Pusić. Pusić mu je bio mentorom i na magisteriju i pri izradi doktorske disertacije. Doktorat znanosti stekao je 1991., obranivši disertaciju pod naslovom "Deformacije organizacijske strukture: hijerarhija i solidarnost". Tijekom karijere Josip Kregar znanstveno se usavršavao na nekoliko međunarodnih uglednih visokoobrazovnih ustanova kao što su Centre for Sociology of Organization i Pantheon-Sorbonne u Parizu, Sveučilište Bocconi Milano i Institut Max Planck Heidelberg.

Od 1999. bio je dugogodišnji predstojnik Katedre za sociologiju. U zvanje redovitog profesora izabran je 2001. godine. U dva je mandata od 2005. do 2009. godine bio dekan Pravnog fakulteta u Zagrebu. Mnogi će trajno pamtiti njegove dekanske aktivnosti. Riječ je o vremenu bitno uvjetovanom uvođenjem bolonjske reforme u visokom obrazovanju, dakle vremenu obilježenom nizom 
neizvjesnosti u daljnjem razvoju nastavne, znanstvene i drugih djelatnosti našeg Fakulteta, ali i cijelog sustava visokog obrazovanja. Svojim pronicljivim i kritičkim pristupom te odlučnim djelovanjem prema nerijetko nepromišljenim i nerijetko politički uvjetovanim pokušajima nametanja određenih izvanakademskih standarda u reformske procese u bitnome je doprinio svrsishodnijem uvođenju bolonjskih načela ne samo na našem Fakultetu nego i u cijelom sustavu obrazovanja. Njegovo aktivno djelovanje u nizu sveučilišnih i izvansveučilišnih tijela, koje je rezultiralo, među ostalim, unapređenjem kadrovskih i prostornih potencijala te promidžbom Fakulteta u okružju, nezabilježeni su do njegova dekanskog djelovanja. Za vrijeme njegovih dvaju mandata na Fakultetu je zaposleno više desetaka asistenata i znanstvenih novaka te osigurani dodatni prostorni uvjeti, što je Fakultetu omogućilo znatno unapređenje znanstvenog i nastavnog djelovanja.

Na pravnom studiju bio je autor, nositelj ili sunositelj niza kolegija: Sociologija, Sociologija prava, Sociologija javne uprave, Ljudska prava, Etika javne službe. Predavao je na hrvatskom i na engleskom jeziku. Osim na doktorskom studiju Pravnog fakulteta u Zagrebu, Josip Kregar držao je predavanja i na drugim studijskim programima, pa tako i doktorskim studijima u Hrvatskoj i u inozemstvu, primjerice na poslijediplomskom studiju Fakulteta za sociologijo, družbene vede i novinarstvo u Ljubljani. Bio je gostujući nastavnik na Sveučilištu u Grazu i Sveučilištu Yale u Sjedinjenim Američkim Državama. Nadalje, bio je jedan od izvršnih direktora poslijediplomskog studija Joint Master in European Integration and Regionalism, koji zajednički izvode Sveučilište u Barceloni, Grazu i Zagrebu te European Academy u Bolzanu i European Institute of Public Administration u Luksemburgu. Od 1998. do 2002. predsjedavao je udrugom Transparency International Hrvatska. Također, predsjedavao je i Upravnim odborom Instituta Otvoreno društvo - Hrvatska i Centra za demokraciju i pravo Miko Tripalo.

Osim svojeg znanstvenog, nastavnog i stručnog djelovanja, Josip Kregar često je i javno promovirao ideje za koje se zalagao. Štoviše, osim kao sveučilišni nastavnik, u široj javnosti ostat će zapamćen kao kritičan, uvjerljiv i angažiran sudionik javnog i političkog života. Od političkih pozicija koje je obnašao valja izdvojiti one povjerenika Vlade Republike Hrvatske za Grad Zagreb, koju je obnašao u proljeće 2000. godine, zastupnika u 7. sazivu Hrvatskog sabora od 2011. do 2015., kada je bio i predsjednik saborskog Odbora za pravosuđe, te kandidaturu za gradonačelnika Grada Zagreba 2009. godine. Za Vladu je izradio Nacionalni program za borbu protiv korupcije 2001. i 2006. godine te Strategiju reforme javne uprave 2002. godine. Bio je autorom Prijedloga zakona o sprječavanju sukoba interesa, zakona o dostupnosti informacija, prijedloga reformi zakona o političkim strankama itd. 
U pogledu znanstvene produktivnosti važno je istaknuti da je Josip Kregar autor i suautor više od stotinu objavljenih znanstvenih i stručnih radova, sveučilišnih udžbenika, monografija, knjiga te nekoliko knjiga političkih eseja. Osim sociologije prava, koja je predstavljala središte njegova znanstvenog interesa, objavljivao je radove i knjige iz područja opće sociologije, ljudskih prava, korupcije, sukoba interesa, javne uprave, problema lokalne uprave i samouprave, problema u pravosuđu, etike u politici itd.

Precizno popisati sve reference njegove znanstvene, nastavne, stručne i javne produktivnosti gotovo je nemoguće. Ponajviše zato što on sam nije previše držao do toga. Bilježio ih je i na taj način dopunjavao svoj životopis samo onda kada su okolnosti to od njega zahtijevale. Stoga nadalje navodim samo pojedine naslove: "Prilozi za studij sociologije", Zagreb, 1997.; "Labour Law Research in Twelve European Countries", Stockholm, 1986.; "Uprava i društvo", Zagreb, 1986.; "The Institutional Framework of Selfmanagement", Zagreb, 1989.; "Die Verfasung der Republik Kroatien: Politische Rahmenbedigungen und Grundlegende Probleme" (suautor) u J. Marko, T. Borić (eds): "Slowenien - Kroatien - Serbien: Die neue Verfassungen”, Böhlau Verlag, Wien, 1991.; "Kroatien und Mitteleuropa", Graz, 1991.; "Corruption and Democracy", Budapest, 1994.; "Political Culture in Central and East Europe", London, 1996.; "Nastanak predatorskog kapitalizma i korupcije”, Zagreb, 1999.; “Javna uprava”, Zagreb, 2001.; "Introduction to the national integrity system study: country report: Croatia 2004” (suautor), Zagreb, 2004.; “Upravljanje sveučilištem” (ur.), Zagreb, 2007.; "Funkcionalna integracija sveučilišta?" (ur.), Zagreb, 2009.; "Korupcija i povjerenje" (suautor), Zagreb, 2010.; "Sociologija javne uprave", Zagreb, 2011.; "Etika u politici i javnoj upravi” (suautor), Zagreb, 2016.; "Opća sociologija s uvodom u sociologiju prava" (suautor), Zagreb, 2020.

Osim u objavljivanju radova bio je vrlo aktivan i u drugim znanstvenoistraživačkim akademskim aktivnostima, od vođenja znanstvenih projekata i programa, izlaganja i priopćenja na velikom broju domaćih i međunarodnih znanstvenih i stručnih skupova.

Svojom pojavnošću, osebujnim pristupom i riječju uvijek je pozivao na propitivanje svih vrijednosti u društvu. Osim onih akademskih. Nisam upoznala čovjeka koji je manje bio vođen vlastitom taštinom od njega. Otvorenost, kritičnost, razumijevanje, pronicljivost bile su dominantne osobine na kojima su se temeljile njegove izrečene ili napisane riječi te njegova djela. Ukratko, bio je - neovisan. Osim o Pravnom fakultetu. Nisam upoznala čovjeka koji je na tako različite načine bio privržen te time iskazivao zahvalnost i poštovanje prema ustanovi na kojoj radi. Dolazeći među prvima, njegov glas odzvanjao je prostorima na Fakultetu i oko Fakulteta te označavao početak radnog, ali nerijetko i 
neradnog dana. Glas koji će, poprimivši već dulje vrijeme formu tradicionalnog institucionaliziranog zvuka, još dugo odzvanjati našim hodnicima.

Odlaskom Josipa Kregara Katedra za sociologiju, Pravni fakultet, Sveučilište u Zagrebu i cjelokupno hrvatsko društvo doživjeli su velik gubitak.

Izv. prof. dr. sc. Ksenija Grubišić*

- Dr. sc. Ksenija Grubišić, izvanredna profesorica Pravnog fakulteta Sveučilišta u Zagrebu, Trg Republike Hrvatske 14, 10000 Zagreb; ksenija.grubisic@pravo.hr; ORCID ID: orcid.org/0000-0003-2464-1438 